\title{
Natural Heritage in the Republic of Kosovo: Looking for Potential UNESCO Sites
}

\author{
Behxhet Mustafa ${ }_{1}^{*}$, Avni Hajdari, Valmir Mustafa2, Bledar Pulaj 1 \\ 1 Department of Biology, Faculty of Mathematical and Natural Science, University of Prishtina, Prishtinë, Kosovo \\ 2 The Regional Environmental Center for CEE Office Kosova, Prishtinë, Kosovo
}

\begin{abstract}
In addition to cultural heritage values, Kosovo is characterised by natural heritage values; these values identify different areas in Kosovo as potential sites for protection under UNESCO's Man and Biosphere (MAB) program and the Convention Concerning the Protection of Cultural and Natural Heritage. These natural values (i.e. geomorphological, hydrological, biodiversity- and ecosystem-related) are found mainly in the massifs of Kosovo's four mountain ranges, i.e. the Sharr Mountains, the Bjeshket e Nemuna (Albanian Alps), the Koritnik Mountains, and the Pashtrik Mountains. These regions provide the largest number of potential sites for nomination to the World Heritage List or the MAB program.

Of the natural heritage values, 19 geomorphological areas of international importance were identified; additionally, 3 areas had regional (Balkan) importance, and 19 sites were caves. Furthermore, 152 glacial and nival lakes and a bifurcation (i.e. hydrological values), approximately 200 species and subspecies that are endemic to the Balkans, 8 locally endemic, 9 endemic and endemic-relict plant associations and 1 endemic animal species (i.e. biodiversity values), and ancient Beech forests (i.e. ecosystem values) were considered for conservation.

Consideration of the above mentioned areas for protection under UNESCO would provide a legal framework for the protection of natural and cultural values in Kosovo as well as support their sustainable development. Additionally, protecting these areas would promote the development of environmental and educational projects and training as well as the research and monitoring of issues related to nature conservation and sustainable development at local, regional and international levels.
\end{abstract}

\section{Keywords:}

Kosovo, Natural heritage, UNESCO, Endemic species, Endemic plant associations

\footnotetext{
*Corresponding author. Email: behxhet.mustafa@uni-pr.edu

(C) The Authors. 2018. Landscape Online. This is an Open Access article distributed under the terms of the Creative Commons Attribution License (http://creativecommons.org/licenses/by/4.0), which permits unrestricted use, distribution, and reproduction in any medium, provided the original work is properly cited.
} 


\section{Introduction}

For the conservation of natural values under the United Nations Educational, Scientific and Cultural Organization (UNESCO), an area may be declared as a World Heritage Site (supported by the World Heritage Convention) or a Biosphere Reserve (supported by the Man and Biosphere (MAB) Program) or both. World Heritage Sites (WHS) are places of importance to all humanity, a significance that is expressed as Outstanding Universal Value (OUV) (UNESCO 1972). In contrast, the MAB program identifies Biosphere Reserves that are model regions for sustainable development (UNESCO 2015). According to the Convention on the Protection of the Cultural and Natural Heritage, World Heritage Sites declared as natural heritage sites refer to (a) natural features consisting of physical and biological formations or groups of formations that have outstanding universal value from an aesthetic or scientific point of view; (b) geological and physiographical formations and precisely delineated areas that contain the habitat of threatened animal and plant species and have outstanding universal value from a scientific or conservation point of view; and c) natural sites or precisely delineated natural areas that have outstanding universal value from a scientific, conservation, or natural beauty point of view (UNESCO 1972). The Convention encourages "States Parties" (Countries which have ratified the Convention) to recognize the duty of ensuring the identification, protection, conservation, presentation and transmission to future generations of the cultural and natural heritage and to develop more general systems for inventorying and conserving both their natural and cultural heritage (UNESCO 1972). By inscription, States Parties intended to ensure that these unique and sometimes vulnerable sites survive into the future, but there is also a recognition that they "can be important for social cohesion and can help to foster a sense of pride," and that they "can also act as the focus for education, tourism and economic regeneration" (English Heritage 2009). The designation of world heritage site requires five steps, as follow:
1. Compilation of the tentative list - the first step a country must take is to make an 'inventory' of its important natural and cultural heritage sites located within its boundaries;

2. Preparation of the nomination file - by preparing a Tentative List and selecting sites from it, a State Party can plan when to present a nomination file. The World Heritage Centre offers advice and assistance to the State Party in preparing this file, which needs to be as exhaustive as possible, making sure the necessary documentation and maps are included. The nomination is submitted to the World Heritage Centre for review and to check that it is complete;

3. The Advisory Bodies - a nominated property is independently evaluated by two Advisory Bodies mandated by the World Heritage Convention: the International Council on Monuments and Sites (ICOMOS) and the International Union for Conservation of Nature (IUCN), which respectively provide the World Heritage Committee with evaluations of the cultural and natural sites nominated. The third Advisory Body is the ICCROM (International Centre for the Study of the Preservation and Restoration of Cultural Property), an intergovernmental organization which provides the Committee with expert advice on conservation of cultural sites, as well as on training activities;

4. World Heritage Committee (WHC) - once a site has been nominated and evaluated, it is up to the intergovernmental World Heritage Committee to make the final decision on its inscription and

5. The criteria for selection - to be included on the World Heritage List, sites must be outstanding universal value and meet at least 1 out of 10 selection criteria (one of the criteria xii-x for natural sites, UNESCO (1996)), see Box 1.

On other hand the MAB program identifies Biosphere Reserves, which must meet a minimal set of criteria to be designated, subsequently forming part of the World Network of Biosphere Reserves 
Box 1: Selection Criteria of Relevance

Criterion vii: to contain superlative natural phenomena or areas of exceptional natural beauty and aesthetic importance;

Criterion viii: to be outstanding examples that represent the major stages of earth's history, including the record of life, significant on-going geological processes in the development of landforms, or significant geomorphic or physiographic features;

Criterion ix: to be outstanding examples that represent significant on-going ecological and biological processes in terms of the evolution and development of terrestrial, freshwater, coastal and marine ecosystems and plant and animal communities;

Criterion $\mathrm{x}$ : to contain the most important and significant natural habitats for the in-situ conservation of biological diversity, including habitats that contain threatened species of outstanding universal value from the scientific point of view.

(WNBR). Biosphere Reserves are designated by the International Coordinating Council of the MAB Programme, at the request of the State concerned (UNESCO, 1996). The official UNESCO criteria for designation as a biosphere reserve are set out in Article 4 of the Statutory Framework of the WNBR (UNESCO, 1996).

General criteria for an area to be qualified for designation as a biosphere reserve:

1. It should encompass a mosaic of ecological systems representative of major biogeographic regions, including a gradation of human interventions.

2. It should be of significance for biological diversity conservation.

3. It should provide an opportunity to explore and demonstrate approaches to sustainable development on a regional scale.

4. It should have an appropriate size to serve the three functions of biosphere reserves.
5. It should include these functions, through appropriate zonation that recognizes:

(a) a legally constituted core area or areas devoted to long-term protection, according to the conservation objectives of the biosphere reserve, and be of sufficient size to meet these objectives;

(b) buffer zones clearly identified and contiguous to the core areas, where only activities compatible with the conservation objectives can take place;

(c) an outer transition area where sustainable resource management practices are promoted.

6. Organizational arrangements should be provided for the participation of a range of inter alia public authorities, local communities and private interests in the design and operation of a biosphere reserve.

7. In addition, provisions should be made for:

(a) mechanisms to manage human use and activities in the buffer zones;

(b) a management policy or plan for the area as a biosphere reserve;

(c) a designated mechanism to implement this policy or plan;

(d) programmes for research, monitoring, education and training.

Although Kosovo is rich in outstanding natural values that align with the relevant criteria, the country does not yet have any sites included on the list of World Heritage Sites or sites designated as biosphere reserves; this is because Kosovo is a young state and is not a member of UNESCO. Thus, screening for potential sites is the first step of the long process involved in nominating potential UNESCO sites in Kosovo.

\subsection{Goals of the study}

The purpose of this study is to highlight outstanding natural areas in Kosovo that meet the relevant criteria, and could later be used to establish World Heritage Sites and Biosphere Reserves. 


\section{Material and methods}

For our evaluation of the natural values in Kosovo, information was gathered from the relevant available literature, which provides information regarding the natural values and biodiversity as well, e.g., for the identification of geomorphologic objects/sites, we used Cvijić, 1901, 1902, 1913; Nopsca, 1905; Nowack, 1926; Çavolli, 1981; Belij, 1990, 1992; Menković 1985; Gavrilović et al. 1998; and Pantić et al., 1998. These findings were synthesised using a comparative approach to identify similar objects in different countries in Europe and around the world, and by analysing the Global Database of Geological Sites (IUGS GEOSITES) and the UNESCO criteria provided by the World Heritage Convention. For the identification of biodiversity values, the following literature was used: Baldacci, 1901, 1904; Košanin, 1913; Bornmuller, 1933, 1935, 1937; Rudski, 1936; Janković, 1958, 1982; Janković \& Bogojević, 1962; Blečić et al. 1968, 1969, 1972; Krasniqi, 1972, 1987, 2008; Rexhepi, 1978, 1982, 1994, 2000; Hundozi, 1980; Stevanović \& Janković 1984; Stevanović et al. 1990; Tatić \& Krivošej, 1997; Krivošej, 1989, 1997; Mustafa, 1998; Mustafa \& Hoxha, 2001; Mustafa at al. 2015; Mala, 2010; and Shuka et al., 2012. Only endemic species were considered; however, for plant associations, both endemic and relict plant associations were considered (but only those that had two dominant species of associations that were endemic and/or relict), as these species were considered to have scientific importance (speciation, evolution, conservation, etc.).

Furthermore, the geographic positions of most of the sites or objects were recorded using GPS (GARMIN eTrex $^{\circledR}$ 30) during fieldwork that was conducted from 2015 to 2017; however, the geographic coordinates of a few sites were derived from the Kosovo geodatabase (http://geoportal.rks-gov.net/). The collected results were processed using GIS (QGIS version 2.18.2).

Identified natural objects present in Kosovo (glacial geomorphology, demonstrated through a range of features, including cirques, deep valleys, high glacial and nival lakes, high mountain peaks and crags with meadows, canyons, caves, as well as the presence of the plant and animal species and plant associations), were checked if they meet one of the four natural criteria (vii-x) of World Heritage Convention. The six cultural criteria (i-vi) were not taken into consideration as the aim of the paper was to highlight only the natural values present in Kosovo. Furthermore, natural sites present in Kosovo were checked to see if they meet the minimum set of criteria and conditions laid out in Article 4 of the Statutory Framework of the World Network of Biosphere Reserves for designation of the Biosphere Reserves (UNESCO, 1996).

\section{Results and discussion}

Although Kosovo is a small county, it is rich in terms of natural values and hosts rich biodiversity, a variety of ecosystems, and various geomorphologies. The largest number of plant species, animal species, ecosystems and geomorphologies are located in the Sharr Mountains, the Bjeshkët e Nemuna (Albanian Alps) Mountains, the Koritnik Mountains, and the Pashtrik Mountains, which are known as centres of biodiversity in the Balkans. Thus, the region's specific relief (related to its glacial geomorphology, demonstrated through a range of features including cirques, deep valleys, high glacial and nival lakes, high mountain peaks and crags with meadows, canyons, rivers as well as the presence of other ecosystems) provides the opportunity to experience the aesthetics of the Balkan mountain landscape.

As the youngest state in Europe, Kosovo is still not a member of UNESCO, despite the fact that it has cultural and natural heritage values. To date, in Kosovo four objects with cultural heritage values, including the Monastery of Deçan (Dečani Monastery), the Patriarchate of Peja (Patriarchate of Peć), the Church in Prizren (Our Lady of Ljeviš) and the Monastery of Graçanica (Gračanica Monastery), have gained protection as one serial World Heritage Site; the first order of protection was announced in 2004 and was extended in 2006 (and is listed under Serbia) 
(https://whc.unesco.org/en/list/724/). However, to date Kosovo does not have any UNESCO heritage sites characterised by natural values, although Kosovo is distinguished by high geomorphological, hydrological, floral, faunal and ecosystem values.

Previous research efforts in Kosovo have identified different natural sites that may potentially qualify for protection under UNESCO programmes. According to Gavrillovic et al. (1998), Kosovo has 41 geomorphological objects with national and international importance. Of them, 19 objects have international importance (international scale), with 14 belonging to glacial relief and 5 belonging to preglacial relief), and 3 objects have regional (Balkan) importance (Tab. 1 and Fig. 1). The pre-glacial and glacial relief elements are mainly located in the Sharr
Mountains, the Bjeshket e Nemuna Mountains, the Pashtrik Mountains and the Koritnik Mountains (Fig. 1). The Sharr Mountains contain eight objects related to glacial relief and three additional objects related to pre-glacial relief. The Bjeshkët e Nemuna Mountains contain five objects related to glacial relief and two objects related to pre-glacial relief, while the Koritnik Mountains contain only one object related to glacial relief. Geo-heritage objects of regional (Balkan) value are related to fluvial relief, i.e., Rugova Canyon (Bjeshket e Nemuna), great peat (turf) in Shutman (Sharr Mountains) and Mirusha Canyon (according to WHC Criteria vii and viii) (Fig. 1.). Furthermore, Kosovo has 19 caves (speleological objects); of these caves, four are active and three are semi-active, while the others are inactive (Bajraktari et al. 2010). Two of these caves are open to visitors, including

Table 1: Natural heritage values in Kosovo, according criteria vii-x of the World Heritage Convention

\begin{tabular}{|c|c|c|c|}
\hline WHC NaturalObjects/Sites & Region & WHC Objects/Sites Name & WHC Criteria \\
\hline \multirow{14}{*}{$\begin{array}{l}\text { Glacial relief with international } \\
\text { importance }\end{array}$} & \multirow{8}{*}{ Sharr Mountains } & Maja e Lubotenit and cirque in PerroiiRopotit spring & viii \\
\hline & & Maja e Kobilicës and cirque in Kobilicë & viii \\
\hline & & Cirque in Vraca e vogël & viii \\
\hline & & Cirque in Rudoke & viii \\
\hline & & Cirques in LumbardhiiPrizrenit springs & viii \\
\hline & & Cirque in Jazhinca & viii \\
\hline & & Cirque in Livadica & viii \\
\hline & & Moraines in the front of LumburdhiiPrizerenit springs & viii \\
\hline & \multirow{5}{*}{ Bjeshkët e Nemuna Mountains } & Cirques around Gjeravica & viii \\
\hline & & Cirque in Rroshkodoll & viii \\
\hline & & Cirques under Leqinatit & viii \\
\hline & & Erratic blocks in the cirque springs in Erenik & viii \\
\hline & & Cirques between Koprivnik and top of Streoc & viii \\
\hline & Koritnik & Cirque in Koritnik & viii \\
\hline \multirow{5}{*}{ Pre-glacial relief } & \multirow{3}{*}{ Sharr Mountains } & Sliding blocks in Vraca e vogël & viii \\
\hline & & Sliding blocks in Rudoka & viii \\
\hline & & Solifluction tongue above the upper lake of Bukorovaçit & viii \\
\hline & \multirow{2}{*}{ Bjeshkët e Nemuna Mountains } & Sliding blocks in Gjeravica above the mountain hut in Plloqic & viii \\
\hline & & Hummocks - grass mounds in Rusolija & viii \\
\hline \multirow{3}{*}{$\begin{array}{l}\text { Glacial relief of regional } \\
\text { (Balkan) importance }\end{array}$} & Sharr Mountain & Great peat (turf) in Shutman & vii and viii \\
\hline & Bjeshkët e Nemuna & Rugova Canyon & vii and viii \\
\hline & Mirusha & Mirusha Canyon & vii and viii \\
\hline \multirow{4}{*}{ Water ecosystems } & Sharr Mountain & 112 are located in the Sharr Mountains, & vii \\
\hline & Bjeshkët e Nemuna Mountain & 34 are in the Bjeshkët e Nemuna Mountains & vii \\
\hline & Koritnik Mountain & 6 are located in the Koritnik Mountains. & vii \\
\hline & Ferizaj & The bifurcation of the Nerodime River & vii and viii \\
\hline \multirow{3}{*}{ Biodiversity (local endemics) } & $\begin{array}{l}\text { Mainly in Sharr, Bjeshket e Nemuna, } \\
\text { Pashtrik Mountain, as well as in central } \\
\text { part of Kosovo. }\end{array}$ & Eight stenoendemic plants (local endemics) & $\mathrm{x}$ \\
\hline & Sharr Mountain. & One local endemic animal species & $\mathrm{x}$ \\
\hline & $\begin{array}{l}\text { Sharr, Bjeshket e Nemuna, Koritnik } \\
\text { and Pashtrik Mountain. }\end{array}$ & One sub-endemic (Balkan) species & $x$ \\
\hline $\begin{array}{c}\text { Significant on-going ecological } \\
\text { and biological processes }\end{array}$ & $\begin{array}{c}\text { Sharr and Bjeshket e Nemuna, } \\
\text { Mountain. }\end{array}$ & European Beech across a variety of environmental conditions & ix \\
\hline \multirow{3}{*}{$\begin{array}{l}\text { Exceptional natural beauty and } \\
\text { aesthetic importance }\end{array}$} & Sharr Mountains & Entire mountain massif & vii \\
\hline & Bjeshkët e Nemuna Mountains & Entire mountain massif & vii \\
\hline & Koritnik Mountains & Entire mountain massif & vii \\
\hline
\end{tabular}


Marble Cave (WHC Criteria vii and viii) in the village of Gadime (area of Lypjan), which formed during the tertiary period and is the only known marble cave in Europe, and Radavci Cave (WHC Criteria vii and viii) near the source of the Drini i Bardhë River (Bjeshkët e Nemuna); Radavci Cave has a length of approximately 1420 metres (including all channels of the cave) (Fig. 1.).

In Kosovo 152 glacial and nival lakes (WHC Criterion vii) are present (i.e., natural hydrological values); from these glacial and nival lakes, 112 are located in the Sharr Mountains, 34 are in the Bjeshkët e Nemuna Mountains, and 6 are located in the Koritnik Mountains. These lakes are primarily located at altitudes greater than 2000 metres. According to Krivokapic (1969), in the Sharr Mountains, the largest glacial lakes are the Lake of Jazhinca and the Lake of Livadica; in the Bjeshkët e Nemuna Mountains, the largest glacial lake is the Lake of Gjeravica (Fig. 1). In terms of hydrological values in Kosovo, the bifurcation of the Nerodime River near Ferizaj represents a potential natural heritage site (WHC Criteria vii and viii), as this formation is unique in Europe and is a rare worldwide example of this type of formation. This stream in Nerodime Village separates into two streams, one of which proceeds to the Aegean Sea and the other to the Black Sea (Fig. 1.). The bifurcation of Nerodime has been under state protection since 1979, and the site was also a strict wildlife sanctuary (Category I, according to the IUCN) until 2015; however, after 2015, the category of the site was changed to that of a natural monument or feature (Category III, according to the IUCN).

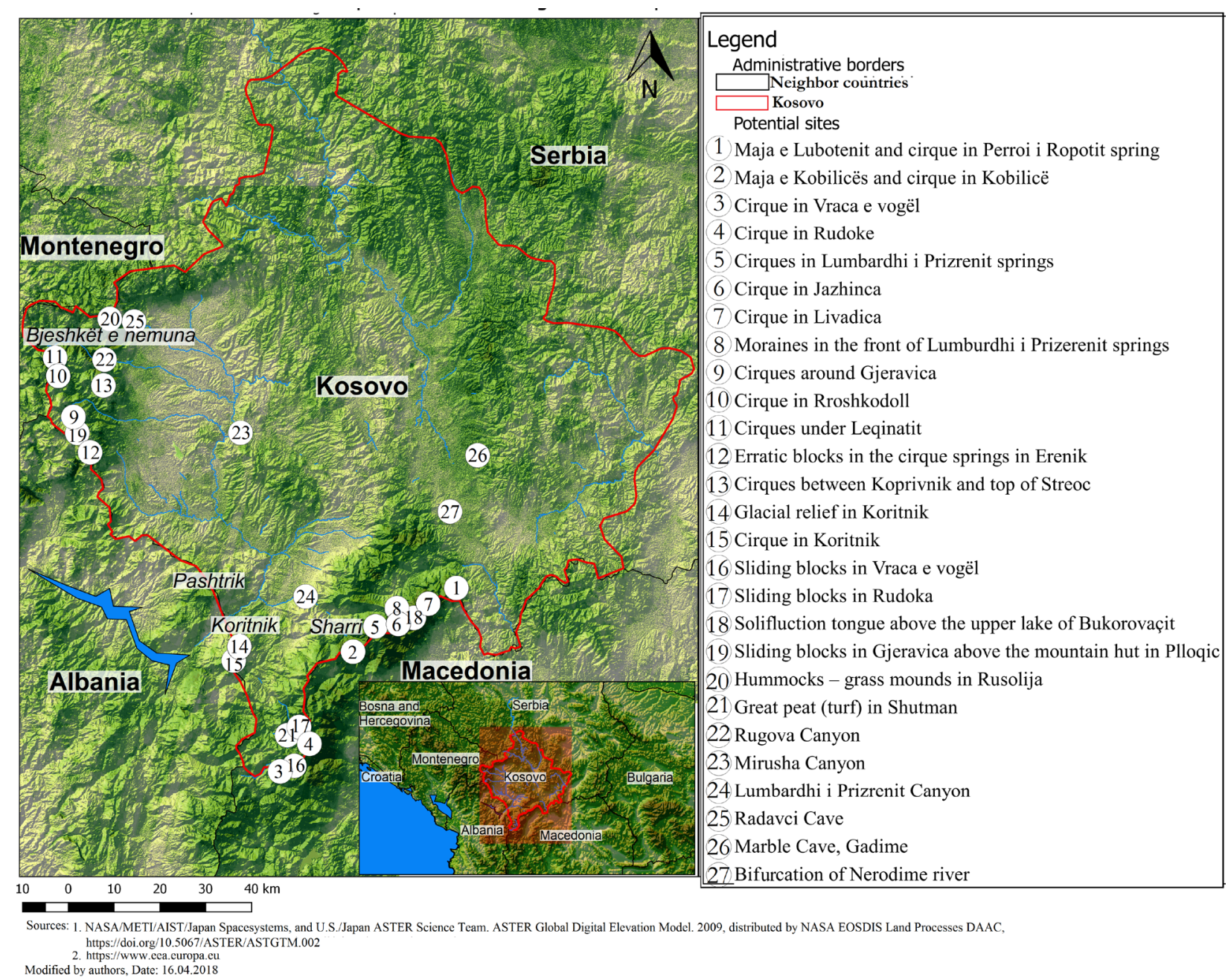

Figure 1: Regional and international geomorphological natural heritage values of Kosovo 
In addition to geomorphological and hydrological values, Kosovo is rich in biodiversity. Biodiversity richness is a result of historical factors (the Balkans region was only slightly influenced by the glacial climate), geomorphological features, hydrological features and climatic features (in Kosovo, there are three types of climate: continental, Mediterranean and alpine). Furthermore, Kosovo contains natural ecosystems (e.g. ancient natural beech forests). Despite the country's small area (i.e. approximately $1.6 \%$ of the Balkans) (Mustafa et al. 2015), Kosovo is rich in plant species that account for $30 \%$ of the Balkan flora (Krasniqi 2008); in fact, approximately 2500 vascular plants species and subspecies (MAB Criterion 2) have been estimated in Kosovo (Krasniqi 2008). Of these plants, in terms of natural heritage (WHC Criterion $\mathrm{x}$ ), stenoendemic (local endemics) and relict species are particularly important. Stenoendemic species are mainly distributed in areas that are already protected areas (i.e. national parks, nature parks, natural monuments); however, most of the species are still endangered. Specifically, Kosovo has eight stenoendemic species, including Achillea alexandri-regis Bornm. \& Rud (OshlakSharr Mountains), Bornmuellera dieckii Degen (Lëndina e Shejtë and Sharr Mountains), Micromeria albanica Griseb, ex K. Maly Silic. (Lumbardh PrizrenSharr Mountains and White Drin Gorge at Ura e Fshejt), Centaurea alberti Rexh., (Deve-Gjakova), Cynoglossum krasniqi Wrab. (Pashtrik Mountains), Tulipa kosovarica (Koznik Mountains), Tulipa serbica Tatić \& Krivošej (Serboc, Mitrovicës), and Wulfenia blecici subsp. rohlenae (Leqinat, Koprivnik-Bjeshkët e Nemuna Mountains) (Fig. 2). Until 2011, Aristolochia merxmuelleri Greuter et Mayer. was known as the stenoendemic species of Kosovo; however, according to (Shuka at al. 2011), this species is also found in the Surroj area near Kukës in the Republic of Albania.

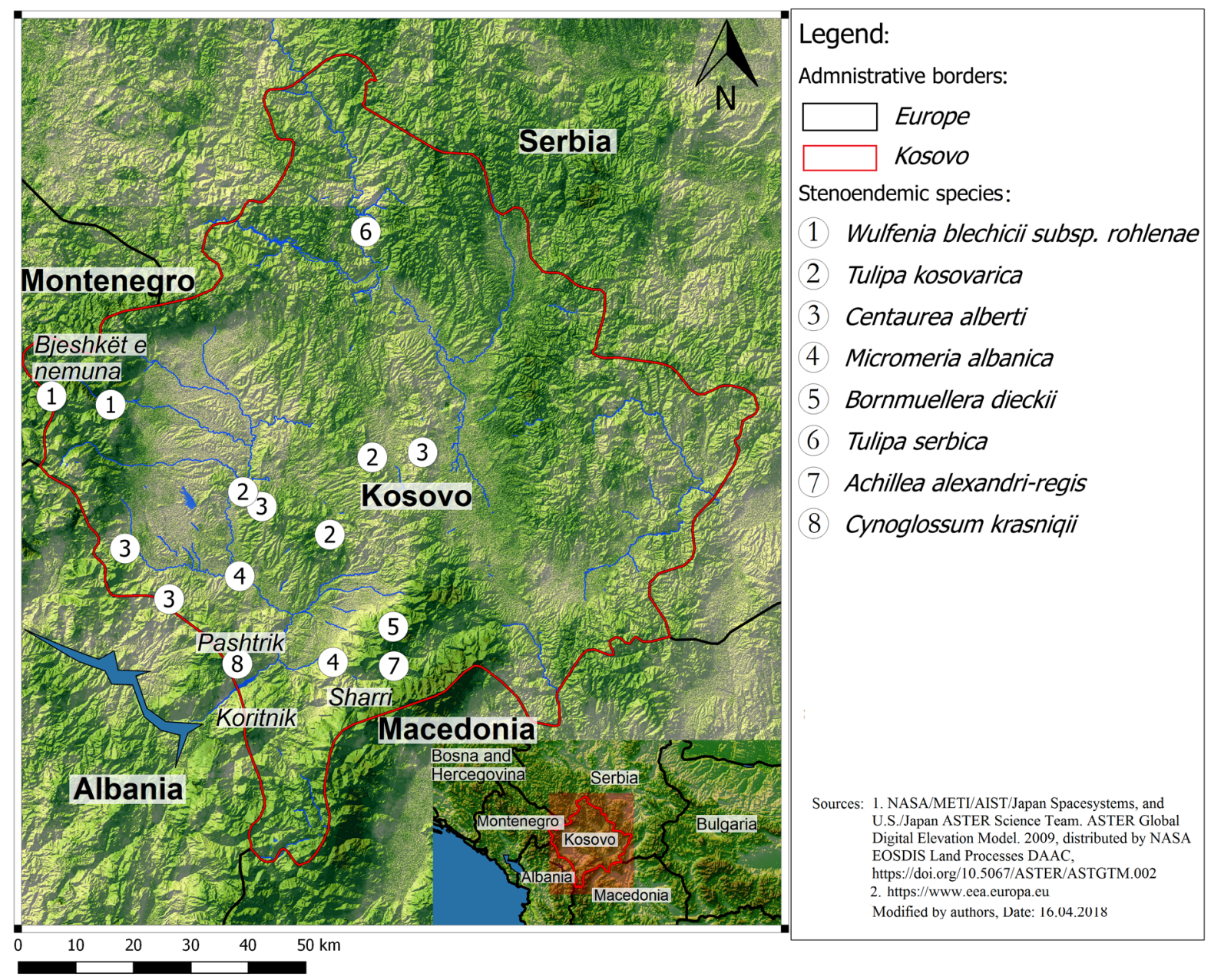

Figure 2: Stenoendemic species and subspecies in Kosovo 
Some of the endemic and endemic-relict plant species in Kosovo have formed associations (phytocoenoses), especially in the serpentine and high mountainous areas. In Kosovo, there are 139 known plant associations (MAB Criterion 1). (Rexhepi, 1994), of which 9 are endemic and endemic-relict (Fig. 3). From the 9 endemic or endemic-relict plant associations, 3 are found in the Sharr Mountains (grassland associations: Achilleo alexandri-regis-Onobrychietum scardicae, SedoBornmullerietum dieckii, and Potentillo doerfleriJuncetum trifidi), 4 are found in the Bjeshket e Nemuna Mountains (shrubbery associations: Polygalo-Forsythietum europaeae; forest associations: Pinetum peucis typicum, Pinetum heldreichii typicum, Wulfenio-Pinetum peucis), one is found in the Koritnik Mountains (forest association: Pinethum heldreichii typicum), and one other is found in the Pashtrik Mountains (grassland association: Polygalo-Genistetum hassertianae); finally, the Onosmo-Scabiosetum fumarioides association is found in Koznik and Zatriç (Fig. 3). In addition to the abovementioned localities, the plant association Polygalo-Genistetum hassertianae is also found in Koznik and Devë (Gjakovo), while the association Polygalo- Forsythietum europaea is also located in the Koznik, Zatriq, Çerret (Gjakovo) and Golesh districts (Fig. 3) (Rexhepi 1994; Jankovic 1998).

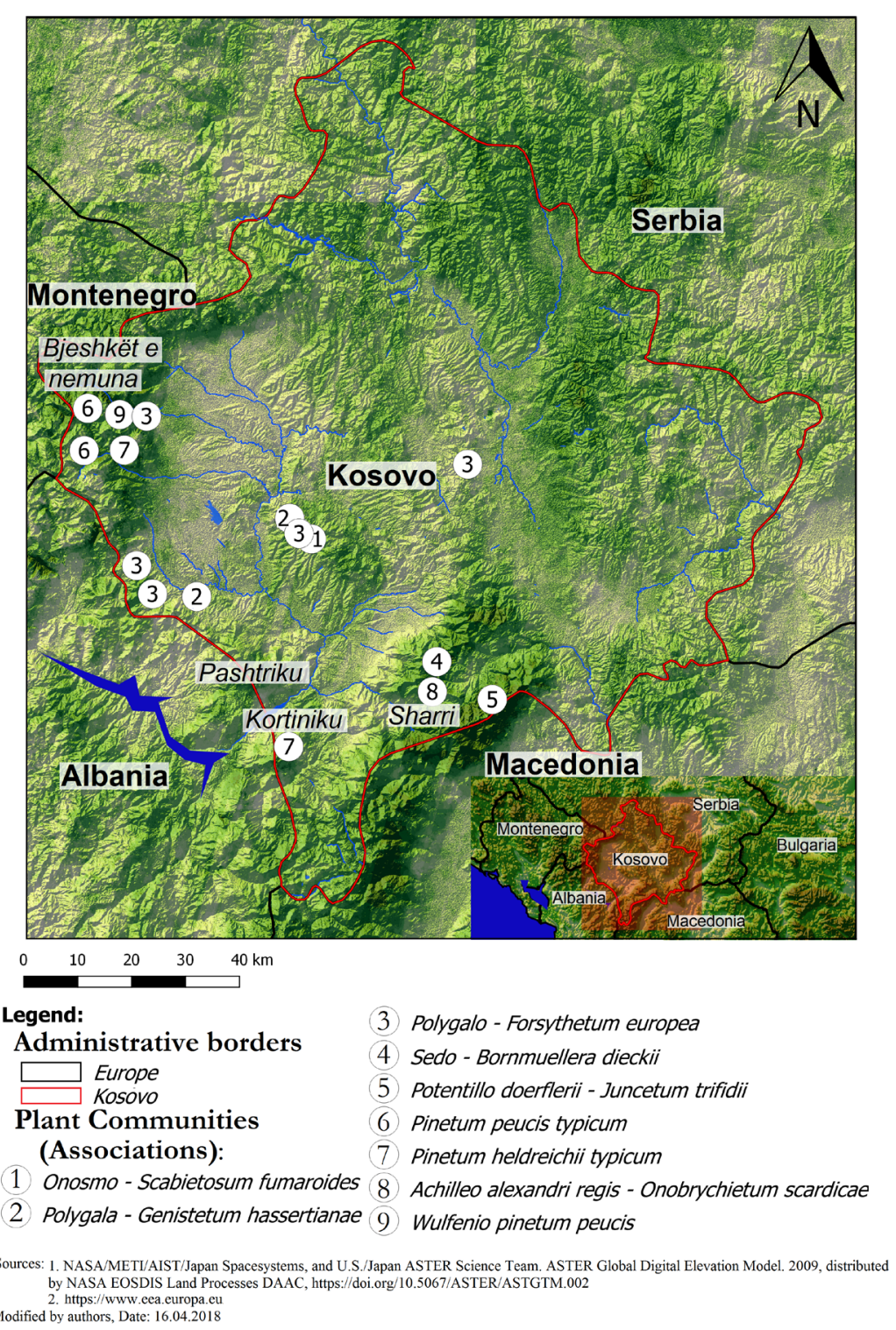

Figure 3: Endemic and endemic-relict plant species associations in Kosovo 
In terms of natural heritage, the important animal species (WHC Criterion $\mathrm{x}$ ) worth mentioning include the Balkan lynx (Lynx lynx ssp. balcanicus), which is classified as endemic to the Balkans due to its special genetic features (Melovski et al. 2012). This species lives in the region including Albania, Macedonia, Kosovo and Montenegro. In Kosovo, this species' habitat is in the Sharr Mountains, the Koritnik Mountains, the Pashtrik Mountains and the Bjeshket e Nemuna Mountains. Another important animal species in the Sharr Mountains is Drusus sharrensis sp. n., which is a local endemic animal species of Kosovo (Ibrahimi et al. 2016). The geomorphological objects, biodiversity as well as plant associations mentioned above are tiny elements of ecosystems, but their concentration mainly in Sharr Mountains, Bjeshket e Nemuna Mountains, Koritnik and Pashtrik Mountains (Figure 1, 2, 3) makes those areas as outstanding universal value from a global point of view.

Furthermore, in Kosovo, ancient natural Beech forests are distributed in both, the Bjeshket e Nemuna Mountains and the Sharr Mountains (the Balkan Peninsula is the main centre of origin and evolution of beech (Janković 1984)), and these beech forests are characterised by high ecological value and serve as genetic reservoirs for many species (Solár et al. 2017). Additionally, these forests comprise outstanding examples of evolutionary and developmental processes (i.e. beech forests emerged after the last glacial period, producing a terrestrial ecosystem that has shaped an entire continent in a globally unique manner) (Kirchmeir \& Kovarovics 2016) and represents an outstanding example of the recolonisation and development of terrestrial ecosystems and communities after the last ice age; a process, which is still ongoing (WHC Criterion ix). The importance of these forests in terms of natural heritage is related to our understanding history and evolution of Fagus, a genus that is widespread in Europe and has global importance. The fauna of Beach forests can exist in all its diversity, and the postglacial evolutionary processes can take place only if each forest development stage of the natural regeneration cycle is present (Pichler et al. 2007; Plachter et al. 2008).
These areas (Bjeshket e Nemuna and Sharr Mountains) are potential transboundary sites for World Heritage sites of the 'Ancient and Primeval Beech Forests of the Carpathians and Other Regions of Europe' (a transnational composition of nature sites) that currently stretches over 12 countries, including Albania (Gashi River and Rrajca) (Kirchmeier \& Kovarovic 2016). It is worth mentioning that ancient beech forests around the Gashi River (Tropoja district in northeastern Albania) and the ancient beech forests of Rrajca (Perrenjas, Elbasan, in central Albania) share very similar characteristics with the ancient beech forests in Kosovo; these similarities demonstrate the post-glacial expansion process and exhibit the most complete and comprehensive ecological patterns and processes of pure and mixed stands of European Beech across a variety of environmental conditions (WHC Criterion ix).

In addition to potential cultural and natural heritage sites, Kosovo has sites that may be appropriate as biosphere reserves, which are protected by UNESCO under the MAB program. Accounting for large areas that are occupied by natural ecosystems, the biological characteristics (i.e. plant species, animal species and vegetation types), ecosystem services (e.g. material goods, regulatory services and cultural services) and economic development aspects based on socio-cultural and ecological sustainable development, the Sharr Mountains $\left(1600 \mathrm{~km}^{2}\right)$ and the Bjeshkët e Nemuna Mountains $\left(3,500 \mathrm{~km}^{2}\right)$ (both national parks: Sharr National Park $53.469 \mathrm{~km}^{2}$ and Bjeshket e Nemuana National Park $62.488 \mathrm{~km}^{2}$ ) are potential sites, that are suitable for biosphere reserves under the MAB program. These sizes can support the three functions of biosphere reserves: a. Conservation of Biodiversity (conservation of landscapes, ecosystems, species and genetic variation); b. Sustainable Development (foster economic and human development which is socio-culturally and ecologically sustainable) and c. Support for Logistics (provide support for research, monitoring, education and information exchange related to local, national and global issues of conservation and development; MAB Criterion 4). Furthermore, these functions can be integrated through appropriate zonation: a. core area, b. buffer zone and c. outer transition area (MAB Criterion 5). 
The Sharr Mountains, in biogeographical and ecological terms, represent one of the most important protected areas in the Balkans. In Sharr National Park alone, there are more than 1500 species of vascular plants, of which approximately $20 \%$ are endemic and relict species of the Balkans (MAB Criterion 2). Sharr National Park is also characterised by a high diversity of vegetation and ecosystems, ranging from sub-Mediterranean plant communities (i.e. lowlands) to the sub-alpine forests dominated by high-altitude Pinus peuce and Pinus heldrechii forests, as well as different herbaceous species and shrubs species that grow on different substrates, such as silicate, limestone and serpentine. Additionally, Sharr National Park is rich in different animal species (WHC Criterion $\mathrm{x}$ ). As well as Sharr National Park, the Bjeshkët Nemuna Mountains are characterised by geomorphological, climatic (sub-Mediterranean, continental and subalpine), geological, pedological and hydrological diversity, which provide a rich diversity of plants and animals and provide unique natural habitats. This unique biodiversity is represented by 1609 taxa (Amidžić 1999) and many plant communities (MAB Criterion 2). From these taxa, beech forests (Fagetum montanum) and endemic pines (Pinetum heldreichii typicum, Pinetum heldreichii thalictretum, Pinetum peucis, and Pinetum mughi typicum) are of interest in terms of conservation. The Bjeshkete e Nemuna Moutains are also rich in terms of animal diversity. To date, 191 butterfly species, 17 fish species, 14 amphibious species, 34 reptiles, over 200 bird species and 38 mammalian species have been recorded. Among mammals, the most representative species include the lynx (Lynx lynx), brown bear (Ursus arctos), European roe deer (Capreolus capreolus), and wild goat (Rupicapra rupicapra) (Amidžić 1999), which are all of interest for conservation. Because of the richness of the ornithofauna, the Sharr Mountains and the Bjeshkët e Nemuna Mountains have been declared as important bird areas (Heath \& Evans 2000).

In these two mountainous areas, cross-border cooperation initiatives for the conservation of nature values can be promoted, as these areas are located in the border areas among Kosovo, Macedonia and Albania (i.e. the Sharr Mountains) and among Kosovo, Montenegro and Albania (i.e. the Bjeshkët e Nemuna Mountains) (UNEP 2010a and 2010b); additionally, Koritnik and Pashtrik could serve as potential transboundary areas between Kosovo and Albania.

The geomorphological objects, biodiversity (including relict and endemic plant and animal species) and plant associations mentioned above are mainly concentrated in the four mountain ranges, which constitute most of the protected area in Kosovo (Fig. 4).

The region's mountain ranges provide the opportunity to experience the aesthetics of the Balkan mountain landscape (WHC Criterion vii); the unique region provides natural processes and functions that enable research on the continued evolution of the landforms (WHC Criterion viii); the region also provides examples of functioning ecosystems that are representative of important natural ecosystems and encourage the protection of the regionally significant biodiversity value (WHC Criterion ix) and enable in situ conservation of biological diversity, including habitats that contain threatened species of outstanding universal value (WHC Criterion $\mathrm{x}$ ).

Furthermore, the number of protected areas identified by the World Heritage and Biosphere Reserve (MAB) program in other Balkan countries is low, even though these other countries are members of UNESCO. For example, neither Bosnia nor Serbia has any World Natural Heritage Sites, Bulgaria has three designated locations); furthermore, Croatia, Montenegro and Slovenia each have only one area declared under UNESCO protection on the basis of their natural values. However, Albania recently declared two component parts of the serial transnational site "Ancient and Primeval Beech Forests" (i.e., Gashi River and Rrajca).

Layering the sites of different administrative states, i.e. the Sharr Mountains (Sharr-Korab-Desha, located in Kosovo, Macedonia and Albania), the Bjeshkët e Nemuna Mountains/Albanian Alps (located in 

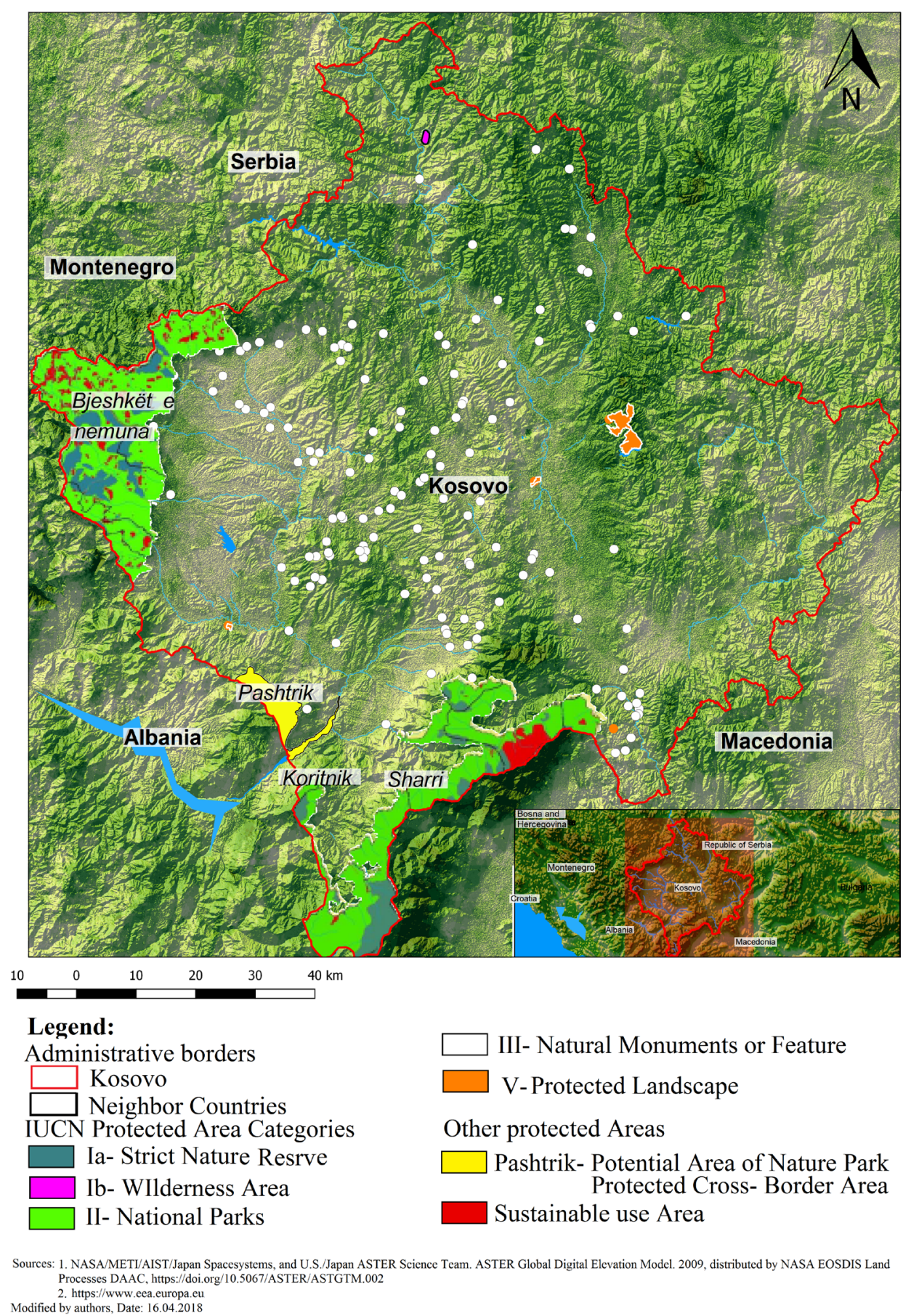

Figure 4: Map of the existing protected areas in Kosovo

Kosovo, Montenegro and Albania), the Pashtrik Mountains (in Albania and Kosovo) and the Koritnik Mountains (in Albania and Kosovo), identified these sites as potential cross-border biosphere reserves. Thus, this identification will contribute to achieving the objectives of the "Dinaric Arc Parks" program, which call for the creation of a network of protected areas that link national parks and nature parks ranging from Albania to Slovenia and objectives of the UNESCO (2015), which are to 1) conserve biodiversity, restore and enhance ecosystem services, and foster the sustainable use of natural resources; 2) contribute to building sustainable, healthy and equitable societies, economies and thriving human settlements in harmony with the biosphere; 3) facilitate biodiversity and sustainability science, 
education for sustainable development (ESD) and capacity building; and 4) support mitigation and adaptation to climate change and other aspects of global environmental change (UNESCO 2015).

\section{Conclusion}

The Republic of Kosovo has distinguished high natural heritage values; however, Kosovo does not yet have any sites declared under protection by UNESCO programs, as Kosovo is not yet a member of UNESCO. The geomorphological objects, biodiversity (including relict and endemic plant and animal species) and plant associations mentioned above represent only a few elements of the ecosystems mainly concentrated in the Sharr, Bjeshket e Nemunas, Koritnik and Pashtrik Mountains, indicating these areas have outstanding universal value from a global point of view and these could represent potential sites for nomination to the World Heritage List or the Biosphere Reserve (MAB program), or both. Thus, screening for potential sites is the first step of the long process involved in nominating potential UNESCO sites in Kosovo. In order to complete the tentative list of the potential sites candidate for World Heritage Convention and MAB programme further research are needed. Furthermore, the identification of these values can be used to increase international attention on the natural heritage of Kosovo and to support national efforts related to the protection of natural values, as well as efforts for membership in UNESCO. Moreover, as these areas are located in the border areas among Kosovo, Macedonia and Albania, the cross-border cooperation initiatives for the conservation of nature values can be promoted. Placing these areas under UNESCO protection would provide a legal framework for the protection of natural and cultural values in Kosovo as well as provide a framework for sustainable management. Additionally, protecting these areas would promote the development of environmental and educational projects and trainings as well as promote the research and monitoring of issues related to nature conservation and sustainable development at local, regional and international levels.

\section{Acknowledgements}

This work was supported by the European Union under grant agreement no. 2014/355-445 (IPA CBC Programme Macedonia-Kosovo 2014-2020). The content of this publication is the sole responsibility of the authors and does not necessarily reflect the officinal views of the European Union.

\section{References}

Amidžić, L. 1999. Visokoplaninska flora i vegetacija. U: Nacionalni Park „Prokletije“ - Nucne i strucne, osnove za zastitu planinskog masiva Prokletija. Arhiv Zavoda za zaštitu prirode Srbije, Belgrade.

ASK (Kosovo Agency of Statistics) http://ask.rks-gov. net/en/kosovo-agency-of-statistics (20.05.2017).

Bajraktari, F.; Behrami, S. \& Katallozi, F. 2010. Shpellat e Kosovës. ProGEO-Kosova, Prishtinë.

Baldacci, A. 1901. Revista della collezione botanika fatia nel 1897 nell' Albania settentrionale. Memorie della R. Accademia delle Scienze di Bologna 5, 9: 227-267. Bologna.

Baldacci, A., 1904: Sulle foreste del Montenegro dell`Albania e dell`Bollettinoufficiale del Ministe rod'Agricoltura,Industriae Commercio.

Belij, S. 1990. Tufuri na Maja Rusoliji. Geomorfologija in ekologija. 5, 149-164.

Belij, S. 1992. Savre menigeo morfološki procesi u krios ferise veroi stočne Šar-planine. Glasnik Srpskog geografs kog društva, vol. 72, bo. 1, pp. 13-24 
Blečić, V.; Tatić, B. \& Krasniqi, F. 1968. Kratk prilog flori Jugoslavije. Glasnik Botaničkog Zavoda i Bašte, Tom III, 1-4. 227-232.

Blečić, V.; Tatić, B. \& Krasniqi, F. 1969. Tri en de mične zajednice na serpentinskoj podlozi Srbije. Acta Botanica Croatica, XXVIII, 43-47.

Blečić, V.; Tatić, B. \& Krasniqi, F. 1972. Zajednica endemičnog šibljaka forzicije (PolygaloForsythietum europaeae Bleč. Et Kras.). Glasnik Republičkog Zavodaza Zaštitu Prirode Prirodnjačkog Muzeja, Titograd. 4: 35-40.

Bornmuller, J. \& Rudski, I. 1935. Achillea alexandriregis, species nova von der Oshljak-Planina. Repertorium specierum novarum regni vagetabilis 38 (13-25), 51-56

Bornmuller, J. 1933. Zur Flora Montenegro, Albanien und Mazedonien, Magyar Botanikai Lapok, 32: 109-142.

Bornmuller, J. 1937. Zur Flora von Mazedonien. Sonderdruck aus Fedde repertorum, 42, 126-142.

Çavolli, R. 1981. Regjionalizimi fizionomik i Sharrit në Territorin e Kosovës. Enti Krahinor për Mbrojtjen e Natyrës, 2.

Cvijić, J. 1901. Glacijalna epoha na Balkanskom poluostrovu. Prosvetni glasnik, 105.

Cvijić, J. 1902 Struktura i podela planina Balkanskog poluostrova. Pristupna akademska beseda. Glas S.K.A., 63, 1, 24.

Cvijić, J. 1913. Ledeno doba u Prokletijama i okolnim planinama. Glas. S.K.A. 91, 188-267.

English Heritage 2009. The Protection \& Management of World Heritage Sites in England. English Heritage Guidance Note to Circular for England on the Protection of World Heritage Sites. London: English Heritage.
Gavrilović, D.; Menkovic, L. \& Belij, C. 1998. Zaštita geomorfoloških objekata u geonaslegju Serbije. Zaštita prirode, 50 .

Heath, M. F.; \& Evans, M. I. 2000. Important Bird Areas in Europe: Priority sites for conservation. Vol. 2. Southern Europe. BirdLife Conservation Series No. 8. - BirdLife International, Cambridge.

Hundozi, B. 1980. Vegetacija nizinskih livada na Kosovu, Dissertation (manuskript), Zagreb.

Ibrahimi, H.; Vitecek, S.; Previšić, A.; Kučinić, M.; Waringer, J.; Graf, W.; Balint, M.; Keresztes, L. \& Pauls, S. 2016. Drusus sharrensis sp. n. (Trichoptera, Limnephilidae), a new species from Sharr National Park in Kosovo, with molecular and ecological notes. ZooKeys 559, 107-124. DOI: $10.3897 /$ zookeys.559.6350

Janković, M. M. \& Bogojević, P. 1962. Prilog poznavanju šuma endemićnih balkanskih borova munike molike (Pinus peuce) na severnoj strani Shar Planine i njenim metohijskim ogranicama, Arhiv bioloških nauka, 14 (3-4), 143-155.

Janković, M.M. 1982. Prilog poznavanju vegetacije Shar Planine sa posebnim osvrtom na neke značajne reliktne vrste biljaka. Glasnik Institutaza botaniku i Botaničke bašte Univerziteta u Beogradu 15, 75-129.

Janković, M.M. 1998. Opšti pregled vegetacijski diversitet Prokletija. Zaštita prirode 50, 41-56.

Janković, M.M. 1984. Vegetacija SR Serbije; istorija i opste karakteristike. 1-173. Vegetacija SR Serbije I. Srpska Akademija Nauka i Umetnosti. Beograd.

Janković, M.M. 1958. Prilog poynavanju munikovih šuma (Pinetum heldrachii) na Metohijskim Prokletijama. Arhiv biološkihn auka 10, (1-4) 5177. 
Kirchmeir, H. \& Kovarovics, A. (eds.) 2016: Nomina on Dossier "Primeval Beech Forests of the Carpathians and Other Regions of Europe" as extension to the exis ng Natural World Heritage Site "Primeval Beech Forests of the Carpathians and the Ancient Beech Forests of Germany" (1133bis). Klagenfurt, 409p

Košanin, N. 1913. Die Verbreitung von Forsythia europaea Deg. Et Bald. in Nord Albanien. Magyrar botanikai Lapok 12.

Kosovo Cadastral Agency, Data Portal. http:// geoportal.rks-gov.net/ (02.10.2018)

Krasniqi, F. 1998. Veçoritë e florës dhe vegjetacionit të Kosovës dhe problemi i mbrojtjes së tyre. Kërkime, 6. Academy of Sciences and Arts of Kosovono. 6. Prishishtinë Kosovë.

Krasniqi, F. 1972. Šumska vegetacija brdskog regiona Kosova. Zajednica naučnih usta nova Kosova studije 27, 1-,133.

Krasniqi, F. 1987. Endemi u flori Kosova i problemi njihove zaštite. Posebna knjiga 83, 119-124.

Krasniqi, F. 2008. Phytodiversity, main component of the biological diversity in Kosovo and the human factor. The environment of Kosova Recourses and Human Factor - Academy of Science and Arts of Kosova.

Krivokapić, D,. 1969. Šar-planina: Turističko-geograf skiprikaz predela i naroda. Turističk a štampa, Beograd.

Krivošej, Z. 1989. Flora planine Grmije kod Prishtine. Magistarski rad., Biološki fakultet, Beograd.

Krivošej, Z. 1997. Vaskularna flora planine Oshljak. Dissertation (manuskript), Biološki fakultet, Beograd.
Mala, XH. 2010. Flora vaskulare e maleve të Mushtishtit. Punimi master, Universiteti i Prishtinës.

Melovski, D.; Ivanov, Gj.; Stojanov, A.; Avukatov, V.; Trajçe, A.; Hoxha, B.; Manuela, A.; Breitenmoser, Ch.; Hristovski, S.; Shumka, S. \& Breitenmoser, U. 2012. Distribution end conservation status of the Balkan Lynx (Lynx Iynx balcanicus Bureš, 1941). Proceedings of the 4th Congress of Ecologists of Macedonia with International Participation Ohrid, Macedonian Ecological Society.

Menković, L. 1985. Glacijalna morfologija Koritnika. Natyra e Kosovës,.6. EKMN.

Mustafa, B. \& Hoxha, E. 2001. Some characteristics of flora and vegetation of Sharr Mountain and their protection. Studime Biologjike 5-6.

Mustafa, B. 1998. Basic characteristics of Flora and vegetation of Kosova an the danger of their disapperarance. Journal of Natural and Technical Sciences 5, 115-121.

Mustafa, B.; Hajdari, A.; Mala, Xh.; Veselaj, Z., Pulaj, B. \& Mustafa, N. 2015. The Pashtrik Mountain, a potential protected landscape area. Biologija. Vol. 61. No.2, 73-82. DOI: 10.6001/biologija. v61i2.3141

Nopsca, F. 1905. Zur Geologie von Nordalbanien. Jahrbuch der kaiserlich-königlichen Geologischen Reichsanstalt 55.

Nowack, E. 1926. Der Nordalbaniche Erzbezirk. Abhandlungen zur praktischen Geologie und Bergwirschaftslehre, Berlin.

UNEP, 2010a. Feasibility Study on establishing a transboundary protected area Prokletije / Bjeshkët e Nemuna Mountains. 
UNEP Vienna ISCC UNEP, 2010b, Feasibility Study on establishing a transboundary protected area Sharr/ŠarPlanina - Korab - Dešat/ Deshat. UNEP Vienna - ISCC.

Pantić, N.; Belij, S. \& Mijović, D. 1998. Geonaslegje u sistemu prirodnih vrednosti i njihova zašstita. Zaštita prirode, 50.

Pichler, V.; Hamor, F.; Vološčuk, I., \& Sukharyuk, D. 2007. Outstanding universal value of the ecologi-cal processes in the primeval beech forests of the Carpathians and their management as World Heritage Sites. Acta ecologica Bratislava: Veda. p. 62.

Plachter, H.; Hoffmann, A.; Panek, N. \& Schmidt, P.A. 2008. European beech forests as a natural site on the World Heritage List of UNESCO. In Knapp, H. D. Beech Forests - a German contribution to the global forest biodiversity. BfN Skripten, 233. Bonn: Bundesampt für Naturschutz (BfN), Federal Agency for Nature Conservation, p. 53-60.

Rexhepi, F. 1978. Zeljaste zajednice brdskog regiona Kosova, Dissertation manuskript, Novi Sad.

Rexhepi, F. 1982. Endemikët e Ballkanit në florën e maleve të Kosovës, Buletini i Fakultetit të Sheken cave Matemeatike dhe Natyrore 8, 211-219.

Rexhepi, F. 1994. Vegetation of Kosova. University of Prishtina, Prishtinë.

Rexhepi, F. 2000. Kosovo endemics plants. University of Prishtina, Prishtinë.

Rudski, I. 1936. O vegetaciji planine Oshljaka. Glasnik Hrvatskog prirodoslovnog društva 41, 118-146.

Shuka, L.; Malo, S. \& Tan, K. 2011. New chorological data and $\mathrm{fl}$ oristic notes for Albania. Botanica serbica. 35 (2), 157-162.
Shuka, L.; Tan, K. \& Kraqsniqi, E. 2012. Tulipa kosovarica (Liliaceae), a new species of tulip from Kosovo. Phytotaxa 62, 1-9. DOI: 10.11646/ phytotaxa.62.1.1

Solár, J.; Janiga, M. \& Šoltěs, R. 2017. "Current Biodiversity and Hotspots in the Primeval Beech Forest - Poloniny National Park, the Eastern Carpathians ( Slovakia )," 1-11.

Stevanović, B. \& Janković. M. 1984. Pregled nekih značajnih endemičnih i reliktnih vrsta visokoplaninske flore Kosovskog dela Shar Planine. Natyra e Kosovës, 55-82.

Stevanović, B., Jovanović, C. \& Lakušić, D. 1990. Potentillo doerfleri- Juncetum trifidii, nova endemična zajednica na silikatima Shar Planine. Glasnik Institutaza botaniku i Botaničke bašte Univerziteta u Beogradu. 22, 77-84.

Tatić, B. \& Krivošej, Z. 1997. Tulipa sebica (Liliaceae), e new species from Serbia. Bocconea 5 (2), 733736.

UNESCO 1972. Convention concerning the protection of the world cultural and natural heritage adopted by the General Conference at its seventeenth session. Paris.

UNESCO, 1996. Biosphere reserves: The Seville Strategy and the Statutory Framework of the World Network. UNESCO, Paris

UNESCO. 1996. Report of the Expert Meeting on Evaluation of general principles and criteria for nominations of natural World Heritage sites (Parcnational de la Vanoise, France, 2224 March 1996), WHC-96.World Heritage List Nominations, UNESCO. https://whc.unesco.org/ en/nominations (02.10.2018)

UNECO 2006. Medieval Monuments in Kosovo. https://whc.unesco.org/en/list/724/ (02.10.2018) 
UNESCO. 2015. MAB STRATEGY 2015-2025. http:// www.unesco.org/new/fileadmin/MULTIMEDIA/ HQ/SC/pdf/MAB_Strategy_2015-2025_final_ text.pdf (Date: 02.03.2017).

UNESCO. 2016. Lima Action Plan 2016-2025. http:// www.unesco.org/new/fileadmin/MULTIMEDIA/ HQ/SC/pdf/Lima_Action_Plan_en_final.pdf (Date: 22.04.2017). 